\title{
Acculturation and dietary habits of Korean Americans
}

\author{
Jeongseon $\mathrm{Kim}^{1 *}$ and Mabel M. Chan ${ }^{2}$ \\ ${ }^{1}$ Department of Food and Nutrition in Oriental Medicine, Semyung University, San 21-1, Shinwol-dong, Chechon, \\ Chungbuk, 390-711, Korea \\ ${ }^{2}$ Department of Nutrition and Food Studies, School of Education, New York University, 35 4th St, 10th Fl., \\ New York, NY 10012, USA
}

(Received 30 September 2002 - Revised 7 October 2003 - Accepted 7 November 2003)

\begin{abstract}
This is the first study to investigate how food and nutrient intakes vary with the levels of acculturation of Korean Americans using a dietary assessment tool tested for validity and reliability. The respondents were Korean Americans $(n$ 486) resident in the Greater New York metropolitan area, USA. They were divided into two groups according to the total score of acculturation: low- and high-acculturated groups. Using a food-frequency questionnaire and a modified Suinn-Lew Asian self-identity acculturation scale, differences in the frequencies of food items, food groups and nutrient intakes consumed were analysed by level of acculturation. The low-acculturated group tended to consume significantly more rice, mixed rice, soyabean paste chigae (pot stew), saengsun (fish) chigae, kimchi chigae, other fish broiled or baked, eggs, kimchi, spinach, persimmons, and white or brown sugar in coffee or tea. The high-acculturated group demonstrated a statistically greater tendency to consume bread, cereal, spaghetti, ham, green salad, sweetcorn, chocolate, candies and diet soft drinks. The more acculturated an individual, the more significant was the tendency to consume sweets. The more acculturated group had significantly $(P<0.05)$ higher intakes of \% energy from total fat, thiamin, vitamin $\mathrm{E}$ and folate, while the low-acculturated group consumed greater amounts of $\mathrm{Na}$, niacin and dietary fibre. The information from the present study can be used to describe dietary habits according to various aspects of acculturation, and allows a better understanding of the dynamics of acculturation and dietary habits.
\end{abstract}

Acculturation: Korean Americans: Diet: Habits

Korean Americans represent one of the fastest growing Asian American groups in the USA; their population has more than doubled during the past decade (US Department of Commerce, 2001). According to a recent census conducted by the Korean Ministry of Foreign Affairs, in December 19992057546 Koreans lived in the USA (Korean Ministry of Foreign Affairs, 2000). New York and New Jersey have the second and third largest numbers of Korean Americans after California. In spite of this increase in immigration, the cultural context of Korean Americans' nutritional intakes have never been explored. Most of the studies of Korean Americans have focused primarily on food patterns (California Korean Health Education and Information and Referral Center, 1990; Kim et al. 1993; Lee, 1998; Lee et al. 1999), but there has only been one study specific to nutritional intakes relating to acculturation issues (Chung, 1995). The various effects of acculturation need to be considered to measure the variations in the daily food intakes of Korean Americans properly.

Acculturation is a process of intercultural borrowing, marked by the continuous transmission of traits and elements between diverse peoples, and results in new and blended patterns (Gove et al. 1993). Acculturation has been shown to influence the dietary habits of immigrants by the retention of or changes in the intakes of foods and nutrients (Kaiser et al. 2001; Satia et al. 2001). Dietary change, within immigrant groups or within groups undergoing acculturation, has become an issue of increasing interest in community nutrition and nutritional anthropology, as more and more populations experience rapid social change (Lands et al. 1990). Migrant studies of first and second generation immigrants to the USA show that acculturation to a western lifestyle appears to result in an increase in morbidity and mortality from many degenerative diseases (Parker et al. 1998). Diseases resulting from dietary habit change have been hypothesized to be the cause of the increase (Huang et al. 1996). Moreover, the increased intake of total energy, fat and sucrose and decreased intake of total and complex carbohydrates, including fibre, have been reported to play a role in the aetiology of the degenerative diseases in migrant population studies (Marmot \& Syme, 1976; Reed et al. 1982). Epidemiological studies of diet and its relationship to various social aspects of a particular population or culture can contribute to the development of nutrition programmes and services in clinical and home settings. Information from these studies is useful in the implementation of such 
programmes and services at federal, state and local levels (Huang et al. 1996).

Acculturation has been viewed as an important variable in the planning of social and psychological intervention for Asian Americans. The process of acculturation is considered as neither linear nor uni-dimensional, but as multi-dimensional, involving changes in behaviours, values and attitudes (Leong, 1986). A validated acculturation scale, Suinn-Lew Asian self-identity acculturation scale (SL-ASIA scale), has been applied to both mental and physical health-related studies, and the same scale has been used in psychotherapy and chronic disease screening in migrant population studies (Gurung \& Mehta, 2001). However, no research has been undertaken that relates the level of acculturation to dietary habits.

The aim of the present study was to identify the correlations between demographic factors and acculturation and then relate the acculturation to dietary habits in Korean Americans residing the Greater New York metropolitan area. The term acculturation is used here to represent the degree to which Korean Americans identify with and are integrated into the majority culture. In the present study, acculturation refers to the language, media use, friendship, foods, pride and ethnic self-identity. Comparing the dietary characteristics of Korean Americans adhering to traditional dietary habits $v$. those adopting more acculturated eating pattern will help researchers to understand and assess the nutritional intakes of the migrant population better and to identify any influence of acculturation on dietary habits.

\section{Methods}

\section{Sample}

The participants were randomly recruited from residential telephone and address books available in Korean American communities residing in the Greater New York metropolitan area. The questionnaires, accompanied by two-dimensional food portion sizes, were posted to 752 Korean Americans; 278 (37\%) and $113(15 \%)$ participants replied to a first and second posting respectively. In an extensive telephone-administered survey (up to three telephone calls) by closely supervised bilingual (Korean-English) interviewers after a prolonged period of training, and additional $16 \%$ of the participants (122 respondents) replied to the questionnaire. All volunteers who participated in this study were of Korean heritage and $\geq 18$ years of age. They all agreed to participate in the study by signing a consent form. The study was reviewed and approved by New York University Human Subjects Committee.

\section{Instrument}

The questionnaire included demographic items, such as age, gender, household income, occupation, length of residence in the USA and questions concerning the acculturation scale. The acculturation level of Korean Americans was measured using a modification of the SL-ASIA scale, which was adapted from an acculturation rating scale for Mexican Americans and has been applied to Asian Americans (Gim et al. 1990). The original SLASIA scale consisted of a twenty-one-item questionnaire covering language, identity, friendship choice, behaviours, generation and geographic history, and attitude. For the present study, six factors believed to be important in determining acculturation were included in a seventeen-item scale. They were language (six questions: spoken at work and/or at home, written, thought, obtained when a child, spoken with friends), media use (three questions: television, radio, media preferred), friendship (four questions: close friends, social gathering preference, friends preferred, offspring's friends), foods (two questions: food preference at home and at a restaurant), pride (one question) and ethnic self-identity (one question). Each question was rated on a scale ranging from very Korean (1) to very American (5). A higher score indicated a higher level of acculturation.

The participants were asked to check if their dietary habits changed after immigration using five scale values from strongly disagree (1) to strongly agree (5). They were then asked to evaluate the types of meals they consumed recently on a scale ranging from very Korean (1) to very American (5).

A food-frequency questionnaire for Korean Americans (KFFQ) was developed by modifying Block's health habits and history questionnaire (Block et al. 1993) to reflect foods consumed by Korean Americans. The KFFQ consisted of 118 food items and standardized measures (portion size, weight, or volume) for each food item were included. The KFFQ was then structured into nine food groups, taking into consideration cultural-specific dietary patterns; it was validated by comparing it with $7 \mathrm{~d}$ dietary records of food items, portion sizes and nutrients (Kim et al. 2002). The previously validated KFFQ was administered to each participant to identify the daily intakes of the 118 food items and nutrients. All written and spoken instruments given to the study participants were provided in both English and Korean. Translations were checked using a translation-back-translation process.

\section{Data collection}

Participants were instructed in detail (both in Korean and English) on how to complete the questionnaire. Additional explanation was provided on the estimation of portion sizes of foods and beverages described in the KFFQ, by food models in picture. All the answers were reviewed after collection and participants were immediately asked, by telephone-administered interview, to clarify any ambiguous or incomplete information if needed. All information collected in the present study was kept strictly confidential; each questionnaire was coded for record keeping and used for data analysis only.

\section{Data analyses}

After all the data collection process, 513 questionnaires (68\%) were completed and among them twenty-seven respondents were excluded for the following reasons: fasting (more than $2 \mathrm{~d}$ ), illness or unusual nutrient intakes 
(extremely high or low values). The final number of participants for data analyses was 486 .

Descriptive statistics, such as mean values and standard deviations, and normality testing, were performed on relevant data using the SPSS 10.0 software package (SPSS Inc., 2000). Of demographic variables, age, length of residence in the USA, education and income were divided into three groups. The trichotomized variables and dichotomized demographic variables (gender and place of birth) were tested if there were any significant differences in acculturation scores.

Intercorrelations of hypothesized demographic variables and acculturation were obtained. The data for total acculturation scores, age, length of residence and education were used as continuous variables, while other variables, such as gender, place of birth, and household annual income were as categorical. In addition, intercorrelations between acculturation (six factors) and changes in dietary habit and type of meals were identified.

The reliability of the acculturation scale was presented as coefficients of internal consistency (Cronbach $\alpha$ ). Acculturation categories are usually adjusted to best reflect the study population. For example, while Suinn et al. (1995) divided their study subjects into low, medium and high levels of acculturation based on total scores, Gim et al. (1990) cross-tabulated acculturation levels by gender and ethnicity: finding that there were no low-acculturated Japanese American men, low and medium scores were collapsed to create one category, low-medium and high, forming two groups instead of the three that Suinn et al. (1995) used. The results of the present study showed that most people had low acculturation scores, unlike those in the study of Gim et al. (1990). Therefore, in the present study we categorized acculturation as low or high.

DietSys ${ }^{\circledR}$ (National Cancer Institute, Bethesda, MD, USA), a computer software program, was modified to analyse the nutrient intake from the KFFQ (Block et al. 1993). Nutrient compositions of Korean ethnic foods were obtained from the recommended daily allowances for Koreans (Korean Nutrition Association, 2000) and incorporated into the DietSys ${ }^{\circledR}$ program. The data editing procedures (range, logical consistency and missing data) were applied using the modified DietSys ${ }^{\circledR}$.

For the purposes of analysis, we determined the mean frequency of consumption per d per person of each food item (total of 118 food items) in the KFFQ. Values were assigned to the nine codes of frequency of consumption, taking into consideration each item's contribution to daily consumption. Never or less than once per month was coded as 0 ; once per month as $0.03(1 / 30)$; twice or three times per month as $0.08(2.5 / 30)$; once per week as $0.14(1 / 7)$; twice per week as $0.29(2 / 7)$; three or four times per week as $0.5(3.5 / 7)$; five or six times per week as $0.79(5.5 / 7)$; once per day as 1.00 ; twice or more per $\mathrm{d}$ as 2.00 . The consumption frequencies of the nine food groups were computed after all the frequencies of food items were combined in each food group. The variables used for the analyses were the mean daily frequencies of the nine food groups, and macro- and micronutrient daily intakes (total energy, protein, total fat, carbohydrate, $\mathrm{Ca}$, $\mathrm{P}, \mathrm{Fe}, \mathrm{Na}, \mathrm{K}$, vitamin $\mathrm{A}$, thiamin, riboflavin, vitamin $\mathrm{C}$, vitamin E, pyridoxine, niacin, cholesterol, dietary fibre, folate and $\mathrm{Zn}$ ) from the KFFQ. ANOVA and general linear model were used to determine if there were any significant differences in the mean values of the low- and high-acculturation groups after controlling for the six demographic variables (Tabachnick \& Fidell, 2000).

\section{Results}

\section{Demographic information}

Table 1 describes the profile of the participants. The majority were female (64\%), middle-aged (37 years old) and from middle-income households $(52 \%$ had incomes ranging from $\$ 25000$ to $\$ 75000$ per year). Most were born in South Korea $(85 \%)$ and were married $(69 \%)$. The average length of residence and education were 9.9 and 14.5 years respectively and the average BMI was $22 \cdot 1 \mathrm{~kg} / \mathrm{m}^{2}$. Most respondents reported that they did not

Table 1. Profile of the respondents $(n 486)^{*}$

\begin{tabular}{|c|c|c|}
\hline & $n$ & $\%$ \\
\hline \multicolumn{3}{|l|}{ Gender } \\
\hline Male & 174 & $35 \cdot 8$ \\
\hline Female & 312 & $64 \cdot 2$ \\
\hline \multicolumn{3}{|l|}{ Place of birth } \\
\hline Korea & 411 & 84.6 \\
\hline USA & 75 & $15 \cdot 4$ \\
\hline \multicolumn{3}{|l|}{ Household annual income } \\
\hline$<\$ 10000$ & 45 & $9 \cdot 3$ \\
\hline$\$ 10000-\$ 14999$ & 24 & 4.9 \\
\hline$\$ 15000-\$ 24999$ & 60 & $12 \cdot 3$ \\
\hline$\$ 25000-\$ 34999$ & 66 & 13.6 \\
\hline$\$ 35000-\$ 49999$ & 90 & 18.5 \\
\hline$\$ 50000-\$ 74999$ & 96 & $19 \cdot 8$ \\
\hline$\$ 75000-\$ 99999$ & 39 & 8.0 \\
\hline$\geq \$ 100000$ & 66 & $13 \cdot 6$ \\
\hline \multicolumn{3}{|l|}{ Marital status } \\
\hline Single & 129 & 26.5 \\
\hline Married & 333 & 68.5 \\
\hline Other (widowed, divorced, separated) & 24 & 4.9 \\
\hline \multicolumn{3}{|l|}{ Smoker } \\
\hline Yes & 78 & $16 \cdot 0$ \\
\hline No & 408 & 84.0 \\
\hline \multicolumn{3}{|l|}{ Exercise } \\
\hline Yes & 144 & $29 \cdot 6$ \\
\hline No & 342 & $70 \cdot 4$ \\
\hline \multicolumn{3}{|l|}{ Vitamin and/or mineral supplements } \\
\hline Yes, fairly regularly & 84 & $17 \cdot 3$ \\
\hline Yes, but not regularly & 141 & $29 \cdot 0$ \\
\hline No & 261 & 53.7 \\
\hline \multicolumn{3}{|l|}{ Change in dietary habits after immigration } \\
\hline Strongly disagree & 51 & $10 \cdot 5$ \\
\hline Disagree & 84 & $17 \cdot 3$ \\
\hline Don’t know & 27 & $5 \cdot 6$ \\
\hline Agree & 216 & 44.4 \\
\hline Strongly agree & 33 & $6 \cdot 8$ \\
\hline Not available & 75 & $15 \cdot 4$ \\
\hline Age (years) $\dagger$ & $36 \cdot 9$ & 11.9 \\
\hline Length of residence in the USA (years) $†$ & 9.9 & $7 \cdot 2$ \\
\hline Education (years) $\dagger$ & 14.5 & 3.4 \\
\hline Height $(m) \dagger$ & 1.636 & 0.077 \\
\hline Weight $(\mathrm{kg}) \dagger$ & $59 \cdot 4$ & 11.7 \\
\hline BMI $\left(\mathrm{kg} / \mathrm{m}^{2}\right) \dagger$ & $22 \cdot 1$ & $3 \cdot 1$ \\
\hline Acculturation $\dagger$ & $2 \cdot 1$ & 0.8 \\
\hline
\end{tabular}

${ }^{*}$ For details of recruitment procedures, see p. 470. † Mean value and standard deviation. 
smoke $(84 \%)$, did not exercise $(70 \%)$ and did not take vitamin and/or mineral supplements (54\%). Over onehalf $(51 \%)$ answered that their dietary habits had changed since they had immigrated to the USA.

The mean score of acculturation was a low $2 \cdot 1$ (on a scale of 1 to 5). Most Korean Americans in the present study had a low level of acculturation in all seventeen items (Table 2). Most reported using the Korean language predominantly, whether at home $(>90 \%)$, with friends $(80 \%)$, thinking $(81 \%)$ or when reading $(63 \%)$. Almost one-half $(48 \%)$ even reported that they spoke mainly Korean at work. Almost all respondents (92\%) had spoken Korean as a child. The majority of respondents $(87 \%)$ reported that they preferred to socialize with other Koreans and that they preferred Korean food ( $82 \%$ when eating at home and $63 \%$ when eating out). Over two-thirds proudly identified themselves as Korean. However, $77 \%$ of the respondents said they wanted their child(ren)'s friends to be equally Korean-American or more American, and that they preferred to listen to media programmes in equally Korean-English or more in English $(63 \%)$.

\section{Demographics and acculturation}

Table 3 shows acculturation scores by demographic variables. Age, place of birth, length of residence in the USA, and education were related to the mean values of acculturation scores. Those who reported higher levels of acculturation to the USA were younger, were born in USA, had stayed longer in the USA and were more highly educated. As presented in Table 4, younger individuals born in the USA, had lived longer in the USA, and were more educated, tended to have a higher level of acculturation.

Table 2. Distribution of acculturation by the respondents to the Korean American food-frequency questionnaire $(n 486)^{\star}$

\begin{tabular}{|c|c|c|c|c|c|c|c|c|c|c|c|c|}
\hline \multirow{2}{*}{$\begin{array}{l}\text { Code... } \\
\text { Item }\end{array}$} & \multicolumn{2}{|c|}{1} & \multicolumn{2}{|c|}{2} & \multicolumn{2}{|c|}{3} & \multicolumn{2}{|c|}{4} & \multicolumn{2}{|c|}{5} & \multirow[b]{2}{*}{ Mean } & \multirow[b]{2}{*}{ SD } \\
\hline & $n$ & $\%$ & $n$ & $\%$ & $n$ & $\%$ & $n$ & $\%$ & $n$ & $\%$ & & \\
\hline $\begin{array}{l}\text { What language(s) do you speak } \\
\text { at work? } \dagger\end{array}$ & 60 & $12 \cdot 3$ & 174 & $35 \cdot 8$ & 93 & $19 \cdot 1$ & 78 & $16 \cdot 0$ & 81 & $16 \cdot 7$ & 2.9 & 1.3 \\
\hline $\begin{array}{l}\text { What language(s) do you speak } \\
\text { at home?t }\end{array}$ & 321 & 66.0 & 114 & 23.5 & 21 & 4.3 & 18 & 3.7 & 12 & 2.5 & 1.5 & 0.9 \\
\hline $\begin{array}{l}\text { In general, what language(s) do } \\
\text { you read? } \dagger\end{array}$ & 201 & 41.4 & 105 & $21 \cdot 6$ & 72 & 14.8 & 66 & 13.6 & 42 & 8.6 & $2 \cdot 3$ & 1.4 \\
\hline $\begin{array}{l}\text { In what language(s) do you } \\
\text { usually think? } \dagger\end{array}$ & 291 & 59.9 & 102 & $21 \cdot 0$ & 39 & 8.0 & 24 & 4.9 & 30 & 6.2 & 0.8 & 1.2 \\
\hline $\begin{array}{l}\text { What language(s) did you use } \\
\text { as a child? } \dagger\end{array}$ & 429 & $88 \cdot 3$ & 18 & $3 \cdot 7$ & 18 & 3.7 & 18 & 3.7 & 3 & 0.6 & 1.3 & 0.8 \\
\hline $\begin{array}{l}\text { What language(s) do you usually } \\
\text { speak with your friends? } †\end{array}$ & 315 & $64 \cdot 8$ & 75 & $15 \cdot 4$ & 39 & 8.0 & 30 & $6 \cdot 2$ & 27 & 5.6 & $1 \cdot 7$ & 1.2 \\
\hline $\begin{array}{l}\text { In what language(s) are the } \\
\text { television programmes that you usually } \\
\text { watch?+ }\end{array}$ & 84 & $17 \cdot 3$ & 84 & $17 \cdot 3$ & 111 & $22 \cdot 8$ & 117 & $24 \cdot 1$ & 90 & 18.5 & $3 \cdot 1$ & 1.4 \\
\hline $\begin{array}{l}\text { In what language(s) are the } \\
\text { radio programmmes that you usually } \\
\text { listen to? } \dagger\end{array}$ & 141 & 29.0 & 72 & 14.8 & 84 & $17 \cdot 3$ & 60 & $12 \cdot 3$ & 129 & $26 \cdot 6$ & 3.0 & 1.6 \\
\hline $\begin{array}{l}\text { In general, in what language }(\mathrm{s}) \\
\text { are the films, television and } \\
\text { radio programmmes you prefer to } \\
\text { watch and listen to? } \dagger\end{array}$ & 111 & $22 \cdot 8$ & 69 & $14 \cdot 2$ & 120 & 24.7 & 114 & 23.5 & 72 & $14 \cdot 8$ & 2.9 & 1.4 \\
\hline Your close friends are: $\dagger$ & 333 & 68.5 & 90 & 18.5 & 42 & 8.6 & 9 & 1.9 & 12 & 2.5 & 1.5 & 0.9 \\
\hline $\begin{array}{l}\text { You prefer going to social } \\
\text { gatherings and parties at which } \\
\text { people are: } \dagger\end{array}$ & 288 & $59 \cdot 3$ & 135 & $27 \cdot 8$ & 45 & 9.3 & 12 & 2.5 & 6 & 1.2 & 1.6 & 0.9 \\
\hline $\begin{array}{l}\text { The persons you visit or } \\
\text { visit you are: } \dagger\end{array}$ & 324 & $66 \cdot 7$ & 117 & $24 \cdot 1$ & 21 & 4.3 & 9 & 1.9 & 15 & 3.1 & 1.5 & 0.9 \\
\hline $\begin{array}{l}\text { If you could choose your } \\
\text { child(ren)'s friends, you would want } \\
\text { them to be? }\end{array}$ & 57 & 11.7 & 54 & $11 \cdot 1$ & 330 & 67.9 & 33 & $6 \cdot 8$ & 12 & 2.5 & $2 \cdot 8$ & 0.8 \\
\hline $\begin{array}{l}\text { What do you usually eat } \\
\text { at home? } \dagger\end{array}$ & 219 & $45 \cdot 1$ & 180 & $37 \cdot 0$ & 57 & $11 \cdot 7$ & 21 & 4.3 & 9 & 1.9 & 1.8 & 0.9 \\
\hline What is/are your favourite restaurant(s)? $\dagger$ & 153 & 31.5 & 153 & 31.5 & 123 & $25 \cdot 3$ & 42 & 8.6 & 15 & $3 \cdot 1$ & $2 \cdot 2$ & $1 \cdot 1$ \\
\hline $\begin{array}{l}\text { If you consider yourself a } \\
\text { member of Korean group, how } \\
\text { much pride do you have } \\
\text { in this group? } \neq\end{array}$ & 171 & 35.2 & 156 & $32 \cdot 1$ & 33 & 6.8 & 123 & $25 \cdot 3$ & 3 & 0.6 & $2 \cdot 2$ & 1.2 \\
\hline $\begin{array}{l}\text { Among the following terms which } \\
\text { best represents you? } \dagger\end{array}$ & 207 & $42 \cdot 6$ & 156 & $32 \cdot 1$ & 99 & 20.4 & 15 & $3 \cdot 1$ & 9 & 1.9 & 1.9 & 1.0 \\
\hline
\end{tabular}

${ }^{*}$ For details of subjects, recruitment and procedures, see Table 1 and p. 470.

†Coded: 1, very (extremely) Korean; 2, more Korean; 3, both equally; 4, more American; 5, very (extremely) American.

$\ddagger$ Coded: 1 , extremely proud; 2 , moderately proud; 3 , little pride; 4 , no pride but do not feel negative toward Korean group; 5 , no pride and do feel negative toward Korean group. 
Table 3. Acculturation scores by demographic variables*

\begin{tabular}{|c|c|c|c|c|c|c|}
\hline Variables & $n$ & $\%$ & Mean & SD & $F$ & $\begin{array}{l}\text { Statistical significance of effect: } \\
\qquad P<\end{array}$ \\
\hline Age (years) & & & & & 31.48 & 0.001 \\
\hline $19-30$ & 133 & $27 \cdot 4$ & $2 \cdot 7$ & 0.9 & & \\
\hline $31-59$ & 293 & 60.3 & $2 \cdot 0$ & 0.5 & & \\
\hline$>60$ & 60 & $12 \cdot 3$ & 1.4 & 0.3 & & \\
\hline Gender & & & & & $2 \cdot 23$ & NS \\
\hline Male & 174 & $35 \cdot 8$ & $2 \cdot 2$ & 0.8 & & \\
\hline Female & 312 & $64 \cdot 2$ & $2 \cdot 0$ & 0.7 & & \\
\hline Place of birth & & & & & 63.41 & 0.001 \\
\hline Korea & 411 & $84 \cdot 6$ & $2 \cdot 0$ & 0.6 & & \\
\hline USA & 75 & $15 \cdot 4$ & $3 \cdot 7$ & 0.5 & & \\
\hline Length of residence in the USA (years) & & & & & $15 \cdot 80$ & 0.001 \\
\hline$\leq 10$ & 284 & $58 \cdot 4$ & 1.9 & 0.5 & & \\
\hline $11-20$ & 163 & 33.5 & $2 \cdot 3$ & 0.9 & & \\
\hline$>20$ & 39 & $8 \cdot 0$ & $3 \cdot 0$ & 1.0 & & \\
\hline Education (years) & & & & & $15 \cdot 83$ & 0.001 \\
\hline$\leq 12$ & 109 & $22 \cdot 4$ & 1.6 & 0.6 & & \\
\hline $13-16$ & 344 & $70 \cdot 8$ & $2 \cdot 2$ & 0.7 & & \\
\hline$>16$ & 33 & 6.8 & $2 \cdot \overline{6}$ & 0.6 & & \\
\hline Household annual income & & & & & $2 \cdot 81$ & NS \\
\hline$<\$ 25000$ & 129 & $26 \cdot 5$ & $2 \cdot 1$ & 0.9 & & \\
\hline$\$ 25000-\$ 74999$ & 252 & 51.9 & $2 \cdot 0$ & 0.6 & & \\
\hline$>\$ 75000$ & 105 & 21.6 & 2.4 & 0.9 & & \\
\hline
\end{tabular}

${ }^{*}$ For details of subjects, recruitment and procedures, see Table and p. 470.

\section{Acculturation, changes in dietary habit and type of meals}

Table 5 shows the correlation between acculturation and changes in dietary habits and types of meals. Changes in dietary habit were correlated positively with language, media use, friendship, food and ethnic self-identity. The types of meals consumed were also positively correlated with the same variable. Those who used the English language and the American mass media had more American friends, ate American food, had an American ethnic self-identity, tended to change dietary habits after immigration and ate American-style meals.

\section{Acculturation and the frequency of consumption of food items and food groups}

Reliability of the modified SL-ASIA scale was high, as demonstrated by a Cronbach $\alpha 0.92$. Respondents were divided into two groups, i.e. low- and high-acculturation groups, to determine whether there were any significant differences in frequencies of consumption of food items,

Table 4. Correlation of demographic variables with acculturation $(n$ 486) $\dagger$

(Correlation coefficients)

\begin{tabular}{lc}
\hline & Acculturation \\
\hline Age & $-0.556^{\star *}$ \\
Gender & -0.117 \\
Place of birth & $0.501^{\star *}$ \\
Length of residence in the USA & $0.378^{\star *}$ \\
Education & $0.417^{\star \star}$ \\
Income & 0.057 \\
\hline${ }^{* *} P<0.01$ (two-tailed). & \\
$\dagger$ For details of subjects, recruitment and procedures, \\
$\quad$ see Table 1 and p. 470.
\end{tabular}

food groups and in nutrient intakes according to the level of acculturation. Table 6 shows the mean frequencies of all 118 food items and of the nine food groups as estimated by the KFFQ and the result of ANOVA performed upon between the two acculturation groups. Significant differences were found in the consumption frequencies of twenty-one food items out of 118. These were: rice, bread, mixed rice and cereal in food group 1 (grain, starch and cereal); spaghetti, lasagne or other pasta with tomato sauce, soyabean paste chigae, saengsun chigae, kimchi chigae and pizza in food group 2 (mixed dishes); ham and lunch meats, other fish grilled or baked, and eggs in food group 3 (meat, fish, poultry and eggs); kimchi, spinach, sweetcorn and green salad in food group 4 (vegetables); persimmons in food group 5 (fruits and juices); sweets and chocolate in food group 6 (sweets); diet soft drinks and white or brown sugar in coffee or tea in food group 9 (beverages). Among the twenty-one statistically significant food items, the low-acculturated group tended to consume significantly more rice, mixed

Table 5. Correlation of acculturation (six factors) with change in dietary habit and type of meals $(n 486) \dagger$ (Correlation coefficients)

\begin{tabular}{|c|c|c|c|c|}
\hline & $\begin{array}{l}\text { Change in } \\
\text { dietary habit }\end{array}$ & Breakfast & Lunch & Dinner \\
\hline Language & $0.430^{\star *}$ & $0.394^{\star *}$ & $0.532^{\star \star}$ & $0.659^{* *}$ \\
\hline Media use & $0.363^{\star *}$ & $0.363^{\star *}$ & $0.453^{\star \star}$ & $0.468^{* *}$ \\
\hline Friendship & $0.303^{* *}$ & $0.374^{\star \star}$ & $0.356^{\star *}$ & $0.472^{\star \star}$ \\
\hline Food & $0 \cdot 215^{\star \star}$ & $0.475^{\star \star}$ & $0.452^{\star \star}$ & $0.519^{\star \star}$ \\
\hline Pride & -0.039 & 0.091 & -0.043 & 0.039 \\
\hline $\begin{array}{l}\text { Ethnic } \\
\quad \text { self-identity }\end{array}$ & $0.344^{\star *}$ & $0.363^{\star *}$ & $0.397^{\star *}$ & $0.533^{\star *}$ \\
\hline
\end{tabular}

** $P<0.01$ (two-tailed).

†For details of subjects, recruitment and procedures, see p. 470. 
Table 6. Frequencies of food items and food groups of two acculturation groups of Korean Americans ( $n$ 486) estimated by the Korean American food-frequency questionnaireł‡

(Mean values and standard deviations)

\begin{tabular}{|c|c|c|c|c|c|c|}
\hline \multirow[b]{2}{*}{ Food item } & \multicolumn{2}{|c|}{$\begin{array}{l}\text { Low acculturation } \\
\qquad(n 246)\end{array}$} & \multicolumn{2}{|c|}{$\begin{array}{l}\text { High acculturation } \\
\qquad(n 240)\end{array}$} & \multirow[b]{2}{*}{$F$} & \multirow{2}{*}{$\begin{array}{l}\text { Statistical } \\
\text { significance } \\
\text { of effect: } P<\end{array}$} \\
\hline & Mean & SD & Mean & SD & & \\
\hline Food group 1 (grain, starch and cereal) & 3.04 & 1.06 & 2.84 & 1.25 & 1.444 & NS \\
\hline Rice $^{\star \star \star}$ & 1.48 & $0 \cdot 70$ & 1.05 & 0.63 & 5.004 & 0.001 \\
\hline Mixed rice* & 0.64 & 0.71 & 0.42 & 0.48 & $2 \cdot 218$ & 0.05 \\
\hline Porridge & 0.02 & 0.08 & 0.03 & $0 \cdot 10$ & 1.323 & NS \\
\hline Bread** $^{* *}$ & 0.33 & 0.37 & 0.53 & 0.45 & 2.913 & 0.01 \\
\hline Bagels & 0.23 & 0.30 & 0.29 & 0.30 & 2.498 & NS \\
\hline Muffins, biscuits & $0 \cdot 12$ & 0.22 & 0.17 & 0.22 & 1.586 & NS \\
\hline Waffles, pancakes & 0.06 & 0.10 & 0.07 & 0.11 & 0.691 & NS \\
\hline Cereal $^{*}$ & 0.14 & 0.25 & 0.25 & 0.43 & 2.437 & 0.05 \\
\hline Cooked cereal & 0.02 & 0.09 & 0.03 & 0.08 & 0.932 & NS \\
\hline Food group 2 (mixed dishes) & $1 \cdot 72$ & $1 \cdot 11$ & 1.52 & 0.76 & 0.792 & NS \\
\hline Noodles, udong & 0.32 & 0.31 & 0.27 & 0.23 & 0.637 & NS \\
\hline Mandu & 0.11 & 0.23 & 0.12 & 0.16 & 1.044 & NS \\
\hline Bibimbap & 0.12 & 0.25 & 0.10 & 0.15 & 0.774 & NS \\
\hline Fried rice & 0.08 & 0.11 & 0.08 & 0.08 & 1.095 & NS \\
\hline Curried rice, hirice & 0.04 & 0.05 & 0.05 & 0.05 & 1.399 & NS \\
\hline Kimbap & 0.07 & 0.08 & 0.06 & 0.05 & 1.394 & NS \\
\hline Sullnongtang, komtang, kalbitang, & $0 \cdot 10$ & 0.16 & 0.06 & 0.07 & 1.553 & NS \\
\hline Soyabean paste chigae $^{\star \star}$ & 0.28 & 0.21 & 0.18 & 0.19 & 3.861 & 0.01 \\
\hline Stewed chicken & 0.04 & 0.09 & 0.03 & 0.05 & 0.857 & NS \\
\hline Yukgejang & 0.08 & 0.17 & 0.04 & 0.06 & $2 \cdot 074$ & NS \\
\hline Saengsun chigae ${ }^{\star *}$ & $0 \cdot 10$ & 0.09 & 0.06 & 0.07 & 2.908 & 0.01 \\
\hline Kimchi chigae* $^{\star}$ & 0.19 & 0.16 & 0.14 & 0.12 & 3.048 & 0.05 \\
\hline Chapchae & 0.04 & 0.05 & 0.04 & 0.04 & 0.740 & NS \\
\hline Pindaedduk, pajeon & 0.05 & 0.07 & 0.04 & 0.05 & 0.230 & NS \\
\hline Spaghetti, lasagne, other pasta with tomato sauce ${ }^{\star \star \star}$ & 0.04 & 0.09 & 0.12 & 0.14 & 9.690 & 0.001 \\
\hline Pizza* $^{*}$ & 0.07 & 0.09 & 0.11 & 0.12 & 3.054 & 0.05 \\
\hline Food group 3 (meat, fish, poultry and eggs) & 2.06 & 1.26 & 1.90 & 1.06 & 1.086 & NS \\
\hline Bulgogi, kalbi & $0 \cdot 18$ & 0.24 & 0.15 & 0.17 & $1 \cdot 221$ & NS \\
\hline Beef steak & 0.12 & 0.16 & 0.09 & 0.09 & 0.633 & NS \\
\hline Pork steak & 0.10 & 0.23 & 0.06 & 0.08 & 0.456 & NS \\
\hline Jangjorim & 0.05 & 0.09 & 0.04 & 0.07 & 0.859 & NS \\
\hline Fried chicken & 0.07 & 0.15 & 0.09 & 0.11 & 2.058 & NS \\
\hline Roasted turkey & $0 \cdot 10$ & 0.03 & 0.07 & 0.04 & 1.989 & NS \\
\hline Hamburgers, cheeseburgers & 0.11 & 0.12 & 0.15 & 0.19 & 1.511 & NS \\
\hline Ham, lunch meats ${ }^{\star *}$ & 0.07 & 0.09 & 0.14 & 0.20 & 3.324 & 0.01 \\
\hline Sausage & 0.07 & 0.14 & 0.07 & 0.10 & 1.864 & NS \\
\hline Bacon & 0.04 & 0.09 & 0.04 & 0.08 & 0.598 & NS \\
\hline Fried fish & 0.08 & 0.11 & 0.06 & 0.10 & 0.927 & NS \\
\hline Sashimi, sushi & 0.08 & 0.10 & 0.07 & 0.10 & 0.141 & NS \\
\hline Shellfish & 0.07 & 0.09 & 0.07 & $0 \cdot 10$ & 0.497 & NS \\
\hline Other fish* & $0 \cdot 16$ & 0.19 & 0.11 & 0.12 & $2 \cdot 275$ & 0.05 \\
\hline Dried anchovies, dried squid & 0.14 & 0.16 & 0.17 & 0.25 & 1.173 & NS \\
\hline Saengsunmuk & 0.08 & 0.11 & 0.09 & 0.11 & 0.416 & NS \\
\hline Jutgal & 0.11 & 0.18 & 0.07 & 0.17 & 1.461 & NS \\
\hline Eggs* & 0.54 & 0.35 & 0.42 & 0.35 & 2.508 & 0.05 \\
\hline Food group 4 (vegetables) & 5.93 & 3.31 & $5 \cdot 23$ & $2 \cdot 88$ & 0.568 & NS \\
\hline Kimchi, kakdugi ${ }^{\star \star \star}$ & 1.55 & 0.59 & 0.98 & 0.62 & $5 \cdot 543$ & 0.001 \\
\hline Bean sprouts, mungbean sprouts & 0.35 & 0.32 & 0.30 & 0.33 & $1 \cdot 751$ & NS \\
\hline Spinach, leek ${ }^{\star \star}$ & 0.26 & 0.25 & 0.17 & 0.17 & 3.854 & 0.01 \\
\hline Lettuce (romaine) & 0.43 & 0.49 & 0.34 & 0.31 & 2.073 & NS \\
\hline Cabbage & 0.15 & 0.20 & 0.17 & 0.28 & 0.390 & NS \\
\hline Broccoli & 0.14 & 0.20 & 0.12 & 0.15 & $2 \cdot 080$ & NS \\
\hline White radish & $0 \cdot 14$ & 0.29 & 0.10 & 0.16 & 1.083 & NS \\
\hline Doraji & 0.05 & 0.09 & 0.04 & 0.07 & $0 \cdot 217$ & NS \\
\hline Kaetnip muchim & $0 \cdot 10$ & 0.17 & 0.07 & 0.10 & 0.795 & NS \\
\hline Muk & 0.05 & 0.07 & 0.04 & 0.08 & 2.058 & NS \\
\hline Green salad* & $0 \cdot 16$ & 0.24 & 0.26 & 0.31 & $2 \cdot 197$ & 0.05 \\
\hline Cauliflower & 0.03 & 0.08 & 0.04 & 0.11 & 0.762 & NS \\
\hline Carrot & 0.33 & 0.39 & 0.35 & 0.39 & 0.663 & NS \\
\hline Cucumber & 0.37 & 0.38 & 0.37 & 0.37 & 0.912 & NS \\
\hline Courgette & 0.30 & 0.34 & 0.26 & 0.31 & 1.072 & NS \\
\hline Tomatoes, tomato juice & 0.24 & 0.35 & 0.24 & 0.28 & 1.689 & NS \\
\hline French fries, fried potatoes & 0.13 & 0.17 & 0.18 & 0.18 & $1 \cdot 207$ & NS \\
\hline Potatoes and sweet potatoes & 0.08 & 0.13 & 0.10 & 0.13 & 1.511 & NS \\
\hline
\end{tabular}


Table 6. Continued

\begin{tabular}{|c|c|c|c|c|c|c|}
\hline \multirow[b]{2}{*}{ Food item } & \multicolumn{2}{|c|}{$\begin{array}{l}\text { Low acculturation } \\
\qquad(n 246)\end{array}$} & \multicolumn{2}{|c|}{$\begin{array}{l}\text { High acculturation } \\
\qquad(n 240)\end{array}$} & \multirow[b]{2}{*}{$F$} & \multirow{2}{*}{$\begin{array}{c}\text { Statistical } \\
\text { significance } \\
\text { of effect: } P<\end{array}$} \\
\hline & Mean & SD & Mean & SD & & \\
\hline Sweetcorn ${ }^{\star *}$ & 0.06 & $0 \cdot 12$ & 0.12 & 0.15 & 3.744 & 0.01 \\
\hline Kongjaban & 0.05 & $0 \cdot 13$ & 0.07 & $0 \cdot 13$ & 1.540 & NS \\
\hline Tofu & 0.37 & 0.24 & 0.35 & 0.32 & 1.311 & NS \\
\hline Mushrooms & 0.23 & 0.28 & 0.27 & 0.26 & 0.923 & NS \\
\hline Miyuk & 0.18 & $0 \cdot 16$ & 0.14 & $0 \cdot 16$ & 1.209 & NS \\
\hline Other seaweed & 0.18 & 0.29 & 0.14 & 0.24 & $1 \cdot 113$ & NS \\
\hline Food group 5 (fruits and juices) & 2.85 & $2 \cdot 34$ & 3.41 & $6 \cdot 66$ & 1.284 & NS \\
\hline Apples, pears & 0.45 & 0.42 & 0.37 & 0.41 & 0.882 & NS \\
\hline Bananas & 0.23 & 0.33 & 0.21 & 0.22 & 1.253 & NS \\
\hline Peaches apricots (canned) & 0.11 & 0.20 & 0.13 & 0.28 & 0.344 & NS \\
\hline Peaches, apricots (fresh) & 0.20 & 0.30 & 0.17 & 0.29 & 0.569 & NS \\
\hline Persimmons ${ }^{*}$ & 0.06 & $0 \cdot 10$ & 0.03 & 0.07 & 2.958 & 0.05 \\
\hline Grapes & 0.13 & $0 \cdot 15$ & 0.15 & $0 \cdot 18$ & 0.663 & NS \\
\hline Pineapples & 0.05 & $0 \cdot 11$ & 0.04 & 0.05 & 0.537 & NS \\
\hline Cantaloupe & 0.14 & 0.20 & 0.11 & 0.39 & 0.653 & NS \\
\hline Watermelon & 0.34 & 0.38 & 0.23 & 0.30 & 1.616 & NS \\
\hline Strawberries & 0.18 & 0.23 & 0.16 & $0 \cdot 17$ & 1.094 & NS \\
\hline Oranges, tangerines, grapefruits & 0.27 & 0.29 & 0.30 & 0.31 & 1.580 & NS \\
\hline Apple juice & 0.16 & 0.24 & 0.15 & 0.24 & 1.047 & NS \\
\hline Orange juice, grapefruit juice & 0.44 & 0.50 & 0.54 & 0.44 & 1.593 & NS \\
\hline Nuts & 0.10 & 0.21 & 0.81 & 6.48 & 1.321 & NS \\
\hline Food group 6 (sweets) ${ }^{\star *}$ & 0.69 & 0.69 & 1.05 & 0.95 & 3.443 & 0.01 \\
\hline Rice cakes & 0.08 & 0.13 & 0.06 & 0.08 & 0.954 & NS \\
\hline Kangjung & 0.09 & 0.02 & 0.02 & 0.06 & $2 \cdot 195$ & NS \\
\hline Ice cream & 0.12 & $0 \cdot 17$ & 0.18 & 0.21 & 1.447 & NS \\
\hline Frozen yogurt & 0.07 & 0.13 & 0.09 & 0.15 & 0.805 & NS \\
\hline Doughnuts, cookies, cakes, pastry & 0.14 & 0.21 & 0.20 & 0.23 & $2 \cdot 358$ & NS \\
\hline Chocolate $^{*}$ & 0.09 & $0 \cdot 18$ & 0.15 & 0.21 & 2.566 & 0.05 \\
\hline Candies** & 0.09 & $0 \cdot 18$ & 0.22 & 0.39 & 3.560 & 0.01 \\
\hline Jelly, jam & 0.09 & 0.17 & 0.14 & 0.24 & $1 \cdot 240$ & NS \\
\hline Food group 7 (dairy products) & 1.08 & 1.22 & 1.06 & 1.08 & $1 \cdot 133$ & NS \\
\hline Whole milk & 0.44 & 0.58 & 0.30 & 0.43 & 1.064 & NS \\
\hline Skimmed and semi-skimmed milk & 0.19 & 0.41 & 0.26 & 0.47 & 1.418 & NS \\
\hline Plain yogurt & 0.12 & 0.25 & 0.09 & $0 \cdot 19$ & 0.619 & NS \\
\hline Low-fat yogurt & 0.06 & 0.18 & 0.07 & 0.19 & 1.008 & NS \\
\hline Cheese & 0.13 & 0.21 & 0.20 & 0.31 & $2 \cdot 358$ & NS \\
\hline Cream cheese & 0.14 & 0.26 & 0.14 & 0.21 & 2.457 & NS \\
\hline Food group 8 (spreads, dressing, oils, fats) & 1.01 & $1 \cdot 12$ & $1 \cdot 18$ & 0.96 & $1 \cdot 153$ & NS \\
\hline Peanut butter & $0 \cdot 10$ & 0.34 & 0.08 & $0 \cdot 16$ & 2.089 & NS \\
\hline Butter & 0.16 & 0.25 & 0.21 & 0.31 & $1 \cdot 132$ & NS \\
\hline Margarine & 0.10 & 0.22 & 0.16 & 0.28 & 1.485 & NS \\
\hline Ketchup & 0.21 & 0.27 & 0.29 & 0.28 & $2 \cdot 194$ & NS \\
\hline Mayonnaise & 0.22 & 0.29 & 0.20 & 0.24 & 1.418 & NS \\
\hline Salad dressing & 0.21 & 0.30 & 0.24 & 0.27 & 1.367 & NS \\
\hline Food group 9 (beverages) & 4.38 & $2 \cdot 84$ & 3.92 & $2 \cdot 60$ & 1.467 & NS \\
\hline Regular soft drinks & 0.39 & 0.48 & 0.42 & 0.47 & 1.717 & NS \\
\hline Diet soft drinks* & 0.06 & 0.19 & 0.18 & 0.40 & 2.469 & 0.05 \\
\hline Beer & 0.06 & 0.14 & 0.10 & 0.20 & 0.969 & NS \\
\hline Soju, chungju & 0.02 & 0.07 & 0.02 & 0.08 & 0.710 & NS \\
\hline Wine & 0.03 & 0.06 & 0.04 & $0 \cdot 10$ & 2.357 & NS \\
\hline Spirits & 0.03 & 0.14 & 0.03 & $0 \cdot 10$ & $2 \cdot 135$ & NS \\
\hline Coffee (caffeinated) & 1.05 & 0.73 & 0.90 & 0.78 & 1.682 & NS \\
\hline Coffee (decaffeinated) & 0.21 & 0.46 & 0.16 & 0.42 & 0.781 & NS \\
\hline Tea & 0.09 & 0.20 & 0.16 & 0.37 & 0.709 & NS \\
\hline Non-dairy creamer & 0.59 & 0.67 & 0.45 & 0.68 & 0.896 & NS \\
\hline Milk in coffee or tea & 0.41 & 0.63 & 0.44 & 0.62 & 0.649 & NS \\
\hline White or brown sugar in coffee or tea* & 0.76 & 0.74 & 0.53 & 0.73 & 2.496 & 0.05 \\
\hline Artificial sweetener in coffee or tea & $0 \cdot 10$ & 0.36 & 0.05 & 0.17 & 0.556 & NS \\
\hline Ginseng & 0.03 & 0.08 & 0.03 & 0.08 & 1.537 & NS \\
\hline Honey, sugar in ginseng tea & 0.05 & 0.15 & 0.05 & 0.23 & 0.709 & NS \\
\hline Sikhe & 0.04 & 0.06 & 0.03 & 0.04 & 1.583 & NS \\
\hline Barley water & 0.47 & 0.74 & 0.33 & 0.65 & 0.997 & NS \\
\hline
\end{tabular}

${ }^{\star} P<0.05,{ }^{\star \star} P<0.01,{ }^{\star \star \star} P<0.001$ (ANOVA and general linear model after controlling for age, gender, length of residence in the USA, education, income and place of birth.

†For details of subjects, recruitment and procedures, see Table 1 and p. 470.

$\ddagger$ Values are given as frequency per $d$ per person; 0.00 , never or less than once per month; 0.03 , once per month; 0.08 , two or three times per month; 0.14 , once per week; 0.29, twice per week; 0.50 , three or four times per week; 0.79 , five or six times per week; 1.00 , once per $\mathrm{d}$; 2.00 , more than twice per $\mathrm{d}$. 
rice, soyabean paste chigae, saengsun chigae, kimchi chigae, other fish grilled or baked, eggs, kimchi, spinach, persimmons, and white or brown sugar in coffee or tea. The high-acculturation group demonstrated a statistically significant tendency to consume more bread, cereal, spaghetti (lasagne, other pasta with tomato sauce), pizza, ham and lunch meats), green salad, sweetcorn, chocolate, candies and diet soft drinks.

The consumption frequencies of the nine food groups were computed after all the frequencies of the food items had been combined. In food group 6 (sweets), both chocolate and sweets were found to be related to acculturation, indicating that the more acculturated an individual is, the greater the likelihood that s/he consumes both of these food items.

\section{Acculturation and nutrient intakes}

The low- and high-acculturation groups were compared to determine if there were any statistically significant differences in nutrient intakes estimated by the KFFQ using ANOVA (Table 7). The nutrients found to be statistically significant were: \% energy from total fat, $\mathrm{Na}$, dietary fibre, folate, vitamin E, thiamin and niacin. The higher the acculturation, the more the \% energy from total fat, thiamin, vitamin $\mathrm{E}$, and folate consumption, and the lower the acculturation, the greater $\mathrm{Na}$, niacin and dietary fibre intakes, and these differences were statistically significant.

\section{Discussion}

Acculturation studies have been incorporated into several studies upon minority food habits, and they have demonstrated the nature of relationships between food habits and availability, racial differences and length of residence (Lewis \& Glaspy, 1975; Newman, 1980). Relatively few studies have reported upon the relationship between nutrient intakes and levels of acculturation; rather, most studies have been performed to describe differences in food intake patterns due to migration.

According to Grivetti \& Paquette (1978), dietary changes occur among Chinese Americans due to acculturation. In another Chinese immigrant food habit study, a statistically significant change in food habits practiced before and after immigration to the USA was identified (Newman, 1980). However, people residing in the USA for $>5$ years showed a significant reversal in some food habits back to traditional Chinese food habits. In that study of Chinese immigrants, $61 \%$ of the respondents reported that their dietary habits had changed after immigration. However, owing to the design of the study, it is not possible to ascertain whether or not there was a reversal in some food habits after a longer period of residence in the USA. The correlation between length of residence in the USA and dietary habit changes was $0 \cdot 31$, indicating that the longer individuals resided in the USA, the more likely they are to alter their dietary habits.

Similar findings were obtained by dietary studies on Korean American, studies that found that the intakes of meat, fruits, milk and fat increased after immigration (California Korean Health Education and Information and Referral Center, 1990; Chung, 1995). As the duration of residence in the USA increased, the consumption of American foods also increased (California Korean Health Education and Information and Referral Center, 1990).

Table 7. Daily nutrient intakes of two acculturation groups of Korean Americans ( $n$ 486) estimated by the Korean American food-frequency questionnairet (Mean values and standard deviations)

\begin{tabular}{|c|c|c|c|c|c|c|}
\hline \multirow[b]{2}{*}{ Nutrients } & \multicolumn{2}{|c|}{$\begin{array}{l}\text { Low acculturation } \\
n 246\end{array}$} & \multicolumn{2}{|c|}{$\begin{array}{l}\text { High acculturation } \\
n 240\end{array}$} & \multirow[b]{2}{*}{$F$} & \multirow[b]{2}{*}{ Statistical significance of effect: $P<$} \\
\hline & Mean & SD & Mean & SD & & \\
\hline Energy (kJ) & 7841 & $1720 \cdot 5$ & 7766 & $1667 \cdot 8$ & 2.054 & NS \\
\hline$\%$ Energy from protein & $16 \cdot 4$ & 2.86 & $16 \cdot 2$ & 3.17 & 1.490 & NS \\
\hline$\%$ Energy from total fat ${ }^{*}$ & $24 \cdot 3$ & 2.57 & $26 \cdot 9$ & 3.95 & 6.375 & 0.05 \\
\hline$\%$ Energy from carbohydrate & $58 \cdot 9$ & $7 \cdot 19$ & $56 \cdot 4$ & 9.37 & 0.937 & NS \\
\hline Protein $(\mathrm{g})$ & $76 \cdot 7$ & $31 \cdot 3$ & 74.9 & $23 \cdot 6$ & 1.668 & NS \\
\hline Total fat (g) & $50 \cdot 5$ & $15 \cdot 0$ & 55.5 & $25 \cdot 0$ & 1.524 & NS \\
\hline Carbohydrate (g) & $275 \cdot 8$ & 24.5 & $261 \cdot 7$ & $57 \cdot 0$ & 0.798 & NS \\
\hline $\mathrm{Ca}(\mathrm{mg})$ & $709 \cdot 8$ & $110 \cdot 9$ & $702 \cdot 0$ & $120 \cdot 0$ & 1.867 & NS \\
\hline$P(m g)$ & 943.5 & 258.5 & $926 \cdot 6$ & 293.5 & 1.954 & NS \\
\hline $\mathrm{Fe}(\mathrm{mg})$ & 12.7 & 3.97 & 13.2 & 4.18 & 2.346 & NS \\
\hline $\mathrm{Na}^{\star \star}(\mathrm{mg})$ & 3034 & $807 \cdot 3$ & 2339 & $705 \cdot 3$ & $10 \cdot 065$ & 0.01 \\
\hline $\mathrm{K}(\mathrm{mg})$ & 1784 & $268 \cdot 7$ & 1733 & 318.5 & 1.424 & NS \\
\hline Vitamin A (RE) & 868.30 & 311.8 & 967.0 & 354.9 & 1.157 & NS \\
\hline Thiamin $(\mathrm{mg})^{*}$ & 1.35 & 0.39 & 1.60 & 0.48 & $6 \cdot 267$ & 0.05 \\
\hline Riboflavin (mg) & 1.67 & 0.57 & 1.42 & 0.69 & 1.360 & NS \\
\hline Vitamin C (mg) & $128 \cdot 3$ & $44 \cdot 3$ & $124 \cdot 6$ & 49.4 & 0.967 & NS \\
\hline Vitamin $E^{\star \star}(\mathrm{mg})$ & 9.90 & $4 \cdot 17$ & $12 \cdot 1$ & 3.86 & 9.426 & 0.01 \\
\hline Pyridoxine (mg) & 1.93 & 0.69 & 2.03 & 0.77 & 1.850 & NS \\
\hline Niacin $(\mathrm{mg})^{\star}$ & $20 \cdot 3$ & 6.09 & 18.7 & 4.08 & 3.468 & 0.05 \\
\hline Cholesterol (mg) & $193 \cdot 8$ & $88 \cdot 2$ & $185 \cdot 5$ & $100 \cdot 2$ & 0.790 & NS \\
\hline Fibre $(\mathrm{g})^{\star *}$ & 11.4 & 3.98 & 8.87 & $3 \cdot 10$ & 8.894 & 0.01 \\
\hline Folate $(\mu \mathrm{g})^{\star \star}$ & 294.3 & $115 \cdot 6$ & $360 \cdot 8$ & $138 \cdot 8$ & 9.031 & 0.01 \\
\hline $\mathrm{Zn}(\mathrm{mg})$ & 9.92 & 3.50 & $10 \cdot 9$ & $7 \cdot 86$ & 0.682 & NS \\
\hline
\end{tabular}

${ }^{\star} P<0.05,{ }^{\star *} P<0.01$ (ANOVA and general linear model after controlling for age, gender, length of residence in the USA, education, income and place of birth). †For details of subjects, recruitment and procedures, see Table 1 and p. 470. 
Chung (1995) also reported that the higher the acculturation level, the less frequently respondents consumed traditional Korean foods.

In the present study, among the nine food groups the frequency of consumption of food group 6 (sweets), in particular, was found to be significantly related $(P<0.01)$ to the level of acculturation. The more acculturated, the higher the tendency to consume food items in the sweets food group. Bertino \& Chan (1986) found that there were differences in sweet and sugar consumption between Chinese (representative of low acculturated recent immigrants) and Americans of European decent (representative of high-acculturated groups), which concurs with the result of the present study.

Researchers have previously examined the relationship between alcohol consumption and the level of acculturation. In several available studies about Latino Americans' dietary practices, acculturation was found to be positively related to both frequency and total amount of alcohol consumed (Black \& Markides, 1993; Otero-Sabogal et al. 1995). An additional study supported the finding that problems associated with alcohol were more frequent and widespread when the Samoan communities were acculturated into the USA mainstream (Hanna \& Fitzgerald, 1993). However, no significant difference in alcohol consumption was found between the two acculturation groups in the present study.

While there is a significant difference $(P<0.05)$ in \% energy from total fat between the low- and high-acculturation groups, the values for \% energy from total fats in both groups are much lower than in the general US population. A recent study on Korean women in New Haven, CT, USA, observed a similar nutrient consumption pattern with acculturation (Chung, 1995). Korean immigrants are likely to assimilate at a slower rate and tend to maintain cultural traditions, especially dietary habits, than other Asian ethnic groups (Kim et al. 1993).

In an ethnic comparative study, there were no significant differences in the intakes of energy and $\mathrm{Na}$ between a recent Chinese immigrant group and a white group (Bertino \& Chan, 1986). However, while $\mathrm{K}$ intake and $\mathrm{K}$ :energy ratio were greater in the white subjects, Na: energy and $\mathrm{Na}: \mathrm{K}$ ratios were greater in the Chinese. The Chinese preferred saltier foods more than the white subjects did, which may also be applicable to Korean Americans and account for the higher $\mathrm{Na}$ consumption in the low-acculturation group in the present study; they consumed more salty traditional Korean foods, such as kimchi and soyabean paste chigae. In a survey by Netland \& Brownstein (1984), who assessed the extent of acculturation and compared the diets of Asian Americans and white subjects, Asian Americans were significantly more likely to have diets that were deficient in vitamin $\mathrm{A}$, riboflavin, $\mathrm{Ca}$ and $\mathrm{Mg}$ than white subjects. In addition, elderly Asians were found to have higher $\mathrm{Na}$, lower $\mathrm{K}$ and lower dietary fat intakes than white subjects.

The intakes of energy, protein, total fat, cholesterol and riboflavin in the present study were similar to those of Chung (1995), and while the intake of $\mathrm{Ca}$ was higher in our present study, the intakes of carbohydrate, vitamin
A, thiamin, vitamin $\mathrm{C}, \mathrm{Fe}$ and niacin were lower. As reported in a study on the nutritional status of elderly Chinese American, Korean American and Japanese American, a large percentage of Korean American elderly were found to consume deficient amounts of protein and vitamins A and C (Kim et al. 1993).

Lewis \& Glaspy (1975) found that when Filipino women migrate to the USA, ethnic food habits are modified, but not abandoned, and that changes are likely to be for the better nutritionally. However, according to Guendelman \& Abrams (1995), first-generation Mexican American women, who are assumed to have a low acculturation level, had higher average intakes of protein, vitamins $\mathrm{A}$ and $\mathrm{C}$, folic acid and $\mathrm{Ca}$ than second-generation Mexican American and white non-Hispanic women.

In the present study, demographic variables, age, place of birth, length of residence in the USA, and education were found to be correlated with acculturation to an US lifestyle after immigration. A similar study, conducted among Koreans in New York, New Jersey and Hawaii found that the acculturation index was related to age, income, education, occupation, gender, and living with or without other family members (spouse or school-aged children) (Lee, 1998). In a Connecticut (USA)-based study, Chung (1995) found that acculturation was significantly related to length of residence in the USA, age, education and occupation. In particular, the most important variable was proficiency in English, which concurs with another study (Lee et al. 1999). In several studies in other minority populations, fluency in English was found to be strongly associated with numerous measures of social adjustment in the USA (Wetermeyer \& Cheng, 1996; Flores, 2000). In a further study of Vietnamese women in the USA using the SL-ASIA scale as an acculturation index, language acculturation was strongly related to attitudes and habits to health practices, such as regular examinations (Yi, 1998).

Although our present results show an overall low level of acculturation, it was possible to categorize respondents into a lower and a slightly higher grouping using a highly reliable acculturation scale and then to compare dietary habits between the two acculturation groups. The present study is the first to consider specific issues regarding nutritional intakes as related to acculturation in the immigrant population using a dietary assessment method tested for its validity and reliability. The information from the present study can be used to describe dietary habits according to the various aspects of acculturation, and allows a better understanding of the dynamics between nutrient intakes and acculturation. It should help researchers to recognize, rather than ignore, specific food consumption patterns $v$. different levels of acculturation among the Korean American population.

\section{Acknowledgement}

This study was partially supported by New York University School of Education Research Challenge Fund. 


\section{References}

Bertino M \& Chan MM (1986) Taste perception and diet in individuals with Chinese and European ethnic backgrounds. Chem Senses 11, 229-241.

Black SA \& Markides KS (1993) Acculturation and alcohol consumption in Puerto Rican, Cuban-American, and MexicanAmerican women in the United States. Am J Public Health 83, 890-893.

Block G, Coyle LM, Hartman AM \& Scoppa SM (1993) $H H H Q$ DIETSYS Analysis Software, Version 3.0. Bethesda, MD: National Cancer Institute.

California Korean Health Education and Information and Referral Center (1990) Korean Health Survey in Los Angeles County. Los Angeles, CA: Korean Health Education and Information and Referral Center.

Chung SS (1995) Dietary change: food habits of Koreans in New Haven. PhD Thesis, University of Connecticut.

Flores G (2000) Culture and the patient-physician relationship: Achieving cultural competency in health care. J Pediatr 136, $14-23$.

Gim RH, Atkinson DR \& Whiteley S (1990) Asian-American acculturation, severity of concerns, and willingness to see a counselor. J Couns Psychol 37, 281-285.

Gove PB, Flexner SB \& Hauck LC (1993) The Random House Dictionary of the English Language, 2nd ed. New York: Random House.

Grivetti LE \& Paquette MB (1978) Nontraditional ethnic food choices among first Generation Chinese in California. $J$ Nutr Educ 10, 109-112.

Guendelman S \& Abrams B (1995) Dietary intake among Mexican-American women: Generational differences and a comparison with White non-Hispanic women. Am J Public Health 85, $20-25$.

Gurung RA \& Mehta V (2001) Relating ethnic identity, acculturation, and attitudes toward treating minority clients. Cult Divers Ethnic Minor Psychol 7, 139-151.

Hanna JM \& Fitzgerald MH (1993) Acculturation and symptoms: A comparative study of reported health symptoms in three Samoan communities. Soc Sci Med 36, 1169-1180.

Huang B, Rodriguez BL, Burchfiel CM, Chyou P, Curb JD \& Yano K (1996) Acculturation and prevalence of diabetes among Japanese-American men in Hawaii. Am J Epidemiol 144, 674-681.

Kaiser LL, Melgar-Quinonez HR, Lamp CL, Johns MC \& Harwood JO (2001) Acculturation of Mexican-American mothers influences child feeding strategies. J Am Diet Assoc 101, 542-547.

Kim J, Chan MM \& Shore RE (2002) Development and validation of a food frequency questionnaire for Korean Americans. Int J Food Sci Nutr 53, 129-142.

Kim KK, Yu ES, Liu WT, Lim J \& Kohrs MB (1993) Nutritional status of Chinese-, Korean-, and Japanese-American elderly. $J$ Am Diet Assoc 93, 1416-1422.

Korean Ministry of Foreign Affairs (2000) Korean American
Census. Seoul: Ministry of Foreign Affairs of the Republic of Korea.

Korean Nutrition Association (2000) Recommended Dietary Allowances for Koreans, 7th ed., Seoul: Korean Nutrition Association Society.

Lands WE, Hamazaki T, Yamazaki K, Okuyama H., Sakai K, Goto Y \& Hubbard VS (1990) Changing dietary patterns. Am J Clin Nutr 51, 991-993.

Lee HK (1998) Food habits of Koreans in the United States. PhD Thesis, New York University.

Lee SK, Sobal J \& Frongillo EA Jr (1999) Acculturation and dietary practices among Korean Americans. J Am Diet Assoc 99, 1084-1089.

Leong FT (1986) Counseling and psychotherapy with AsianAmericans: Review of the literature. J Couns Psychol 33, 196-206.

Lewis JS \& Glaspy MF (1975) Food habits and nutrient intakes of Filipino women in Los Angeles. J Am Diet Assoc 67, 122-125.

Marmot MG \& Syme SL (1976) Acculturation and coronary heart disease in Japanese-American. Am J Epidemiol 104, 225-247.

Netland PA \& Brownstein H (1984) Acculturation and the diet of Asian-American elderly. J Nutr Elder 3, 37-56.

Newman JM (1980) Chinese immigrant food habits: a study of the nature and direction of change. PhD Thesis, New York University.

Otero-Sabogal R, Sabogal F, Perez-Stable EJ \& Hiatt RA (1995) Dietary practices, alcohol consumption, and smoking behavior: ethnic, sex, and acculturation differences. J Natl Cancer Inst Monographs 18, 73-82.

Parker SL, Davis KJ, Wingo PA, Ries LAG \& Health CW (1998) Cancer statistics by race and ethnicity. CA Cancer J Clin 48, 31-48.

Reed D, McGee D \& Cohen J (1982) Acculturation and coronary heart disease among Japanese men in Hawaii. Am J Epidemiol 115, 894-905.

Satia JA, Patterson RE, Kristal AR, Hislop TG, Yasui Y \& Taylor VM (2001) Development of scales to measure dietary acculturation among Chinese-Americans and Chinese-Canadians. $J$ Am Diet Assoc 101, 548-553.

SPSS Inc. (2000) SPSS Professional Statistics 10.0. Chicago, IL: SPSS Inc.

Suinn RM, Khoo G \& Ahuna C (1995) The Suinn-Lew Asian self-identity acculturation scale: Cross-cultural information. J Multicult Couns Devel 23, 139-148.

Tabachnick BG \& Fidell LS (2000) Using Multivariate Statistics, 4th ed., New York: Harper Collins College Publishers.

US Department of Commerce (2001) 2000 Census of the Population. US Summary. Washington, DC: US Government Printing Office.

Westermeyer J \& Cheng H (1996) English fluency and social adjustment among Hmong refugees in Minnesota. J Nerv Mental Dis 184, 130-131.

Yi JK (1998) Acculturation and Pap smear screening practices among college-aged Vietnamese women in the United States. Cancer Nurs 21, 335-341. 